\title{
A Seasonal Comparison of the Effectiveness of Parent Engagement on Student Literacy Achievement
}

\author{
Cathlene Hillier \\ Crandall University
}

\begin{abstract}
Parent engagement is often promoted as a remedy for reducing achievement gaps between students from high socio-economic and low socio-economic backgrounds. However, researchers have found mixed results when examining parent engagement and student outcomes. Drawing on a study investigating the effectiveness of summer literacy camps offered by schools in Ontario, I compare the influence of parent engagement on two outcomes: (1) spring snapshot of cumulative learning, and (2) summer literacy growth/loss. In considering summer learning in regression analysis, I aim to investigate the effect of parent engagement without the influence of schools during the academic year. Out of 14 parent engagement measures, I find only three (parents' aspirations, home resources, discussions of school with children) are positive predictors of spring literacy outcomes and that none predict summer literacy growth/loss. Family socio-economic status remains a powerful predictor of
\end{abstract}

Canadian Journal of Education / Revue canadienne de l'éducation 44:2 (2021) 
achievement for both outcomes. I interpret my findings within three proposed mechanisms of parent engagement: cultivation ethic, realist reaction, and expressive logic.

Keywords: parent engagement, literacy achievement, socio-economic status, inequality, summer learning, summer literacy camp(s)

\section{Résumé}

L'engagement des parents est souvent présenté comme un remède pour réduire les écarts de rendement entre les élèves issus des milieux socioéconomiques élevés et faibles. Cependant, les chercheurs ont constaté des résultats mitigés lorsqu'ils ont examiné l'engagement des parents et les résultats des élèves. En m'appuyant sur une étude portant sur l'efficacité des camps d'alphabétisation estivaux offerts par les écoles de l'Ontario, je compare l'influence de l'engagement des parents sur deux résultats : 1) l'aperçu printanier de l'apprentissage cumulatif, et 2) la croissance ou la perte d'alphabétisation durant l'été. En considérant l'apprentissage estival dans une analyse de régression, je cherche à étudier l'effet de l'engagement des parents sans l'influence des écoles pendant l'année scolaire. Sur quatorze mesures de l'engagement des parents, je constate que trois seulement (les aspirations des parents, les ressources à la maison, les discussions sur l'école avec les enfants) sont des prédicteurs positifs des résultats de l'alphabétisation au printemps et qu'aucune ne prédit la croissance ou la perte de l'alphabétisation lors de l'été. Le statut socioéconomique de la famille demeure un puissant indicateur de la réussite pour les deux résultats. J'interprète mes conclusions en fonction de trois mécanismes proposés pour l'engagement des parents : 1'éthique de la culture, la réaction réaliste et la logique expressive.

Mots-clés : engagement des parents, alphabétisation, statut socioéconomique, inégalité, apprentissage estival, camp(s) d'alphabétisation d'été

\section{Acknowledgement}

This research was supported in part by funding from a SSHRC Insight Grant [435-2013-0730]. 


\section{Introduction}

Parent engagement ${ }^{1}$ in children's schooling has received widespread support from education policy makers, as it is conceptualized as one solution in increasing student achievement (e.g., Australian Government, Department of Education, Employment and Workplace Relations, 2012; Ontario Ministry of Education, 2010; U.S. Department of Education, 2004). Despite the fanfare, researchers have found mixed results when examining parent engagement and student outcomes. Some scholars have found that many types of parent engagement do not substantially improve academic achievement (Domina, 2005; Fan \& Chen, 2001; Hill \& Tyson, 2009). Others found that parent engagement has an influence on student achievement depending on the subject matter, age of the child, and ethnicity (Fan et al., 2012; Patall et al., 2008).

Seasonal studies on educational achievement have highlighted the impact of children's out-of-school time and its contribution to the disparities between advantaged and disadvantaged students (Alexander et al., 2007; Davies \& Aurini, 2013; Downey et al., 2008; Heyns, 1978). That is, students fare better when they are in school (rather than during the summer months), and this positive effect makes the most difference for students from low socio-economic (SES) backgrounds (Kim \& Quinn, 2013; Raudenbush \& Eschmann, 2015). Thus far, seasonal research designs have been used to examine summer's effect on learning and children's body mass index (Downey, 2018; von Hippel \& Workman, 2016), but there has been little focus on examining parent engagement within this comparative approach. When school is not in session, parents are the main providers of children's learning opportunities and are primarily responsible for structuring their out-of-school time. If parent engagement is as influential as its promoters suggest, then it should show substantial effects on outcomes when children are not in school, and their learning is completely dependent on family activities and resources. If parental engagement is not effective in positively affecting achievement, then other forms of literacy intervention should receive the attention of policy makers, rather than promoting parent engagement.

1 The term parent engagement is used to describe parents' involvement in their children's schooling such as volunteering, attending school functions, and supporting learning at home (e.g., reading, helping with homework) (Epstein, 1995). 
This study tests the effects of parent engagement on literacy achievement within a strategic new testing ground: summer. Drawing on a study investigating the effectiveness of summer literacy camps offered by Ontario, Canada's public schools (Davies \& Aurini, 2010-2014), I use data on literacy achievement for a non-random sample of 1,671 students (Grades 1-3) from 230 schools to compare the effects of parent engagement on two literacy outcomes: cumulative achievement and summer growth/loss. Multilevel linear models are employed to answer two research questions: Which measures of parent engagement positively affect student cumulative literacy learning and summer literacy growth/loss? In terms of literacy achievement and SES, which students benefit the most from parent engagement practices?

The present research builds on previous parent engagement literature in two key ways. First, the seasonal design of the study allows for a comparison of parent engagement on two literacy outcomes. Studying parent engagement in a seasonal research design answers the call for more research utilizing a counterfactual approach to examining school versus family processes (Downey, 2018). Second, I test the parent engagement mechanisms outlined below, and expand on these findings by speculating why parent engagement is not measuring up to the expectations of educational policy makers.

\section{The Mechanisms of Parent Engagement and Literacy Outcomes}

Economic, cultural, and social capital are consistently linked to gaps in educational outcomes between higher- and lower-SES families, and parent engagement is often viewed as a way to compensate for these disparities (Domina, 2005). Thus, education policy and practice have sought to improve student achievement by improving parent-school connections, encouraging parents to be more involved, and giving parents a voice in school activities (e.g., Ontario Ministry of Education, 2010). In this section, I outline the research on parent engagement and children's literacy, propose three mechanisms that influence parents' involvement, and discuss the relationship that different forms of engagement have with academic achievement. ${ }^{2}$

2 The three mechanisms of parent engagement were adapted from the literature and developed from correspondence between the author and Scott Davies (January 2017). 
The cultivation ethic. In her seminal ethnographic study, Lareau (2011) theorizes that middle-class parents are more likely to adopt a logic of "concerted cultivation," where parents facilitate opportunities for each child's unique physical, emotional, and intellectual growth through intensive involvement in schooling and extracurricular activities. Parent engagement in schooling is one of the most evident areas where this philosophy of parenting has burgeoned (Schaub, 2010). Related to economic, cultural, and social capital theories, middle-class parents are more inclined to provide a wide array of learning resources for children at home, see children's schooling as a collaborative effort with schools, expect to work with schools and intervene as needed to advance children's academic progress, and see themselves as equals with teachers (Bourdieu, 1998; Horvat et al., 2003; Lareau, 1989). In contrast, working-class and poor parents espouse a logic Lareau (2011) dubs "accomplishment of natural growth," where parents love and take care of children's emotional and physical needs, but education and the provision of academic enrichment is primarily left to schools. Relatedly, lower- and middle-class parents have different resources to draw on.

Building on Lareau's (2011) work, the cultivation ethic is a philosophy of parenting that is related to SES, and can result in parents having higher aspirations for their child's future education, providing educational resources in the home, or enrolling children in a variety of extracurricular activities. The objective, in the parent's view, is to foster a well-rounded child, as well as to cater to the child's specific talents. While parents may or may not do these things with academic achievement in mind, the factors included in this group tend to have a positive relationship with educational outcomes. For example, high parental aspirations and expectations are consistently linked to positive effects on student achievement (Englund et al., 2004; Fan \& Chen, 2001; Galindo \& Sheldon, 2012; Jeynes, 2005).

The realist reaction. Some engagement strategies could be explained by a realist reaction from parents (Epstein, 1988; McNeal, 2012); that is, parents (with varying SES levels) react to their child's current academic accomplishments and respond accordingly. If a child struggles with reading, parents might increase reading and homework time, hire a tutor, or regularly meet with the teacher to gauge progress. This mechanism makes sense in explaining why a measure, such as homework help, often has a negative or no significant relationship with achievement (e.g., Cooper et al., 2006). Using a combined 
measure of home-engagement strategies (e.g., checking homework, reading with child), Galindo and Sheldon (2012) find a negative association between these strategies and academic outcomes. However, other studies examined these interventions separately and found mixed results. Homework help is shown to have a negative relationship or no relationship in some studies (Jeynes, 2005; Robinson \& Harris, 2014), and a positive relationship in others (Domina, 2005; Patall et al., 2008). Other strategies receive positive results, such as reading with the child at home and discussing school with children (Jeynes, 2005; Robinson \& Harris, 2014). Additionally, Domina (2005) found a negative association between attending parent-teacher conferences and achievement, while Robinson and Harris (2014) only found this negative association for children who have parents with a high school education or less. Overall, because parents are responding to a child's lower achievement, the variables related to this mechanism often result in a negative relationship with achievement.

The expressive logic. At-school engagement strategies could be explained by an expressive logic. Parents become involved in school council, volunteer for a school trip or attend a school assembly because they want to be involved. This mechanism is not directly related to a child's academic performance, but, rather, out of parents' availability, desires, or interests to become involved. In a combined measure of school engagement (e.g., attending events, volunteering), El Nokali and colleagues (2010) found a negative association with literacy achievement, while others found a positive association (Englund et al., 2004; Galindo \& Sheldon, 2012). In examining these measures separately, parent council participation has a negative association for all parents, but attending school events is significantly positive for parents with a middle-income (Jeynes, 2005; Robinson \& Harris, 2014), and volunteering at school shows a small positive association (Domina, 2005). In sum, considering variables related to the expressive logic as something parents do out of interest is useful in explaining the mixed results these variables often have on academic achievement.

\section{Parent Engagement and Summertime}

Accounting for all non-school time, summertime is the longest period for inequalities in family capital and resources to affect children's academic growth (Heyns, 1978). In the 
few summer learning studies that include measures of family resources and engagement, practices that have a positive affect on summer literacy scores include at-home reading activities (Burkam et al., 2004; Slates et al., 2012), visits to the library, and parents' high expectations for school work (Slates et al., 2012). Alternatively, Borman and colleagues (2005) found that parental expectations and learning activities in the home did not explain the differences in summer achievement, but parents' efforts to ensure daily attendance at summer school reduced learning loss. While these studies consider family practices/ resources, they do not include parents' efforts at school, such as communication with the teacher, which can influence school-year learning and summer progress. Parents who meet with their child's teacher could gain insight into learning activities they could do during the summer to boost their child's learning. In addition, these scholars do not compare the effect of these measures on summer outcomes versus a snapshot of literacy skills or school-year growth. Davies and Aurini (2013) present the only study that compares the impact of these measures on school year and summer literacy scores, including an overall measure for parents' school participation. However, they do not include measures of parents' participation at home (e.g., reading, homework help, and discussing school with the child).

To provide an in-depth focus on parent involvement, this article builds on previous research by adding more measures for engagement at school and home. By examining the individual effects of the various forms of parent engagement, I can parse out the types of involvement that positively affect student literacy achievement during summer versus previous learning. Additionally, I add interaction effects of parent engagement measures by SES in order to see if certain strategies are beneficial for specific groups. Below, I describe the study, present findings, and discuss the results as they relate to the three mechanisms of parent engagement. I conclude by discussing the implications that these findings have for education policy and programs.

\section{Methodology}

I use data collected as a part of a longitudinal mixed methods project evaluating an intensive summer literacy intervention offered by Ontario elementary schools for Grades 1-3 (Summer Learning Project [SLP]). Using a seasonal learning design, each year, student 
literacy skills are tested in late June and again in early September. Four principal sets of data are merged for the current study: literacy achievement scores (spring and fall), administrative data from schools (e.g., attendance, reading grades), parent survey (questions regarding family resources, parent involvement in schooling), and school information gleaned from online resources (e.g., school enrolment).

The sample consists of 1,671 cases of students from 230 schools that have parent survey data (with complete data on one parent's education level) and literacy scores for spring and fall, collected in 2010 and 2011. This sample includes children in both the test (attendees of the SLP) and control groups, and who were enrolled in elementary schools in Ontario. Primarily, surveys were filled out by mothers and female guardians/caregivers (71\%). Child participants were in Grade 1 (38\%), Grade 2 (37\%), or Grade $3(25 \%)$, and $52 \%$ of children in the sample are male. The schools chosen to operate summer literacy programs typically have high levels of at-risk populations and, therefore, this non-random sample is not representative of the population of students within Ontario. Another limitation is that the survey response rate was $37 \%$, which can result in bias in the variety of responses. ${ }^{3}$ Despite its limitation in generalizability, the SLP contains Canada's most comprehensive data on parent engagement, and is the only Canadian study using a seasonal learning research design to date.

\section{Outcome Variables}

Student spring and fall literacy scores were measured using the Standardized Test for the Assessment of Reading (STAR), ${ }^{4}$ which evaluates phonetic awareness, general reading capabilities, comprehension, and vocabulary. Initially, students answer questions with varying levels of difficulty, and the program routes them to a test aimed at their learning level. When the test is completed, STAR converts the item-response scores to grade-equivalent scores based on national norms. For example, a grade-equivalent score of 1.3 means that a student has a reading level of the average Grade 1 student in the third month of the school year. There are two outcome measures included in this analysis.

3 Notably, Davies and Aurini (2013) find that the survey responders and non-responders did not have significantly different literacy scores $(p>.05)$.

4 For information about the STAR literacy test, see https://www.renaissance.com/products/star-early-literacy/ 
First, cumulative learning is determined by spring literacy scores. This snapshot measure includes all learning up to that date. Second, summer learning growth/loss is determined by subtracting fall scores from spring literacy scores.

Independent variables. All independent variable definitions and sources are listed in Table 1 (Appendix 1). The parent survey asked questions about parent involvementassociated with common measures of cultural and social capital - in their children's education, as well as questions about student disposition toward schooling and involvement in extracurricular activities. I use several questions from the survey as my level-1 independent variables that fall into three categories. First, family and child sociodemographic measures include: family SES, male student, English as the primary language spoken at home, child born in Canada, and marital status of parents. Second, there are the variables that fall into the three parent engagement mechanisms. The cultivation ethic category includes parent aspirations for their children's education (from graduating high school up to attending graduate school); the amount of time the child spends watching TV; the amount of time the child spends on computers or other digital devices; home educational resources (e.g., books, computer); extracurricular activities (e.g., organized sports, music/ dance lessons); and whether a parent has discussions about school with the child. ${ }^{5}$ The realist reaction category includes whether a child has a tutor or not; the number of hours of weekly homework; if a parent reads frequently with the child; and meetings with the teacher. ${ }^{6}$ Parent engagement categories, such as volunteering in school, attending school events (e.g., open houses, assemblies), serving on school council, and if a parent does fun activities with the child at home, ${ }^{7}$ are added to measure the expressive logic. Third, there are four measures for student academics: average language grade from the previous school progress report, days late, days absent, and whether or not the child liked school.

Level-2 predictors include school type (public or Catholic) and school size. Finally, four control variables are included in all of the models: test interval (amount of time

5 I created scales for home resources (Cronbach's alpha $=0.843)$ and extracurricular activities $($ alpha $=0.712)$.

6 I combined respondents' answers to two questions regarding parent-teacher meetings (attended a parent-teacher meeting and met with teacher privately) (alpha $=0.727)$.

7 I combined the activities that parents said they did with their child several times per week: games (e.g., puzzles, board games), music (e.g., play, sing, dance), sports (e.g., informal sports played at home, such as catch), and watch television or play video games (alpha $=0.894)$. 
between the two tests), cohort (2010 or 2011 cohort), grade level (1-3), and attending SLP.

Missing data. The parent survey and school-level items used for this study have 0.18 to $29.86 \%$ rates of non-response. This missing data can create bias in the results and reduce statistical power to substantially estimate the effect of independent variables. Therefore, I use multiple imputation (mi impute chained) procedures in Stata 13 to compensate for missing values. This procedure accounts for the missing cases that would otherwise be discarded through listwise deletion by using the existing values of variables in the complete dataset to create plausible estimates to account for missing values. Multiple imputation creates several data sets which are then combined and averaged to generate a single set of estimates to account for missing data. Due to the highest rate of non-response (almost 30\%), I follow von Hippel's (2009) rule of thumb where the number of imputations is similar to the percentage of incomplete cases. Therefore, 30 imputations are performed for each model. Descriptive statistics for non-imputed and imputed data are listed in Table 2 (Appendix 2). For almost all variables, the imputed mean is almost identical or quite close to the original mean, indicating that the imputations created plausible estimates of missing values. Importantly, there is little to no missing data on parent engagement variables which are the main focus of the analysis. Also, because SES is an important variable in the analysis, the highest level of education for the parent who filled out the survey is complete.

Statistical procedure. Since parent engagement is reported to vary by SES, I first present bivariate statistics by SES quartiles. Next, in order to answer the research questions, I use multilevel models to account for the variability between level-1 observations (families) and the contextual variability that may exist between level-2 clusters (schools) (Snijders \& Bosker, 2012). Families nested in schools tend to share the same neighbourhood, and, as a result, their responses may be correlated due to these similarities. For each outcome variable, I build regression models sequentially with groups of covariates. The first model contains the measure for family SES, the other sociodemographic measures, and the control variables. In the second model, I add the parent engagement mechanism covariates. The third model includes the student academic measures and level-two variables (school type and school size). Finally, the fourth model includes interactions where 
the SES measure is multiplied by each parent involvement activity to determine who benefits from the various forms of parent engagement. Interactions between two variables reveal the combined effects of these factors on the dependent variable. If these interactions only show gains in literacy outcomes for students from high-SES backgrounds, then parent engagement as a solution for boosting low-achievement among students from lowSES backgrounds is not advantageous (Domina, 2005).

\section{Results}

\section{Bivariate Statistics by SES}

Table 3 provides parent engagement measures by SES. There are slight differences in the average outcome of cumulative literacy scores for the first three groups (mean 1.97; $2.19 ; 2.28)$, and the top quartile has a more sizeable difference by comparison (2.69). Further, the third and fourth quartiles $(.01 ; .07)$ show average gains in literacy during the summer months, while the first and second quartiles show average losses (-.08; -.03). In terms of the cultivation ethic where parents facilitate and oversee educational and extracurricular activities, children in the second, third, and top quartiles, on average, have more resources, participate in more extracurricular activities, and discuss school with parents more often in comparison with children in the bottom quartile. The children in the top quartile have slightly more television and computer time than their peers, and spend slightly less time on homework. Also, the top two quartiles have the highest means in the variable "parents' aspirations" which is the highest level of education parents hope their children will achieve. This is important to highlight because, while other parent engagement categories receive mixed results, parents' aspirations are consistently linked to students' achievement.

Considering the realist reaction where parents respond to their child's low or high achievement, the third and top quartiles have higher means in meeting with the teacher and receiving tutoring support, but show lower means for engagement in reading and homework help. For the expressive logic where parents are involved in certain activities out of interest or availability, the third and top quartiles have higher means in all the school-based involvement categories: volunteering, attending a school event, and 
participating on parent council. This is not surprising, since previous research indicates that middle-class parents generally feel more comfortable being in schools and have work schedules that afford the time to participate in parent council and other school events (Horvat et al., 2003). However, the top quartile has a lower mean for playing games, music, sports, and TV/video games at home. Overall, the parent engagement variables reveal slight differences by SES quartiles. Notably, in categories that are often linked to children's learning at home (e.g., reading, homework help), the top quartile has lower means in these categories than the other three quartiles.

\section{Table 3}

Family Level Descriptive Statistics by SES $(N=1671)$

\begin{tabular}{|c|c|c|c|c|c|}
\hline & $\begin{array}{c}\text { SES } \\
\text { Quartile 1 }\end{array}$ & $\begin{array}{c}\text { SES } \\
\text { Quartile 2 }\end{array}$ & $\begin{array}{c}\text { SES } \\
\text { Quartile } 3\end{array}$ & $\begin{array}{c}\text { SES } \\
\text { Quartile } 4\end{array}$ & $F$ Statistic \\
\hline \multicolumn{6}{|l|}{ Outcomes (min, $\max$ ) } \\
\hline Spring literacy $(0,12.9)$ & $1.97(.07)$ & $2.19(.06)$ & $2.28(.07)$ & $2.69(.11)$ & $386.76^{* * *}$ \\
\hline Summer growth/Loss $(-11.4,4.3)$ & $-.08(.03)$ & $-.03(.03)$ & $.01(.04)$ & $.07(.06)$ & $76.14 * * *$ \\
\hline \multicolumn{6}{|l|}{ Demographics } \\
\hline English spoken at home $(0,1)$ & $.90(.02)$ & $.93(.01)$ & $.88(.02)$ & $.89(.02)$ & $65.73 * * *$ \\
\hline Born in Canada $(0,1)$ & $.82(.02)$ & $.84(.02)$ & $.78(.02)$ & $.77(.03)$ & $77.59 * * *$ \\
\hline Married/Common law $(0,1)$ & $.59(.03)$ & $.80(.02)$ & $.88(.02)$ & $.96(.02)$ & $1533.21^{* * *}$ \\
\hline \multicolumn{6}{|l|}{ Level-1 Independent Variables } \\
\hline \multicolumn{6}{|l|}{ Cultivation Ethic } \\
\hline Aspirations $(1,4)$ & $2.25(.06)$ & $2.49(.04)$ & $2.72(.05)$ & $2.86(.07)$ & $820.08 * * *$ \\
\hline TV time $(0,3)$ & $1.57(.03)$ & $1.54(.02)$ & $1.53(.03)$ & $1.63(.04)$ & $48.03 * * *$ \\
\hline Computer time $(0,3)$ & $1.53(.05)$ & $1.65(.04)$ & $1.69(.04)$ & $1.77(.06)$ & $108.79 * * *$ \\
\hline Home resources $(1,6)$ & $3.26(.06)$ & $3.47(.05)$ & $3.59(.05)$ & $3.78(.08)$ & $357.13^{* * *}$ \\
\hline Extracurricular $(1,7)$ & $1.54(.06)$ & $1.68(.04)$ & $1.77(.05)$ & $1.95(.07)$ & $300.78^{* * *}$ \\
\hline Discuss school $(0,1)$ & $.83(.02)$ & $.91(.01)$ & $.93(.01)$ & $.94(.02)$ & $234.21 * * *$ \\
\hline \multicolumn{6}{|l|}{ Realist Reaction } \\
\hline Hired tutor $(0,1)$ & $.07(.01)$ & $.10(.01)$ & $.11(.02)$ & $.17(.03)$ & $147.64 * * *$ \\
\hline Time on homework $(0,3)$ & $2.05(.03)$ & $2.02(.02)$ & $2.03(.03)$ & $2.00(.04)$ & $11.11^{* * *}$ \\
\hline Read with $(0,1)$ & $.87(.02)$ & $.91(.01)$ & $.91(.01)$ & $.88(.03)$ & $39.92 * * *$ \\
\hline Met teacher $(0,2)$ & $1.27(.04)$ & $1.33(.03)$ & $1.41(.03)$ & $1.51(.04)$ & $205.17 * * *$ \\
\hline
\end{tabular}




\begin{tabular}{lccccc}
\hline & $\begin{array}{c}\text { SES } \\
\text { Quartile 1 }\end{array}$ & $\begin{array}{c}\text { SES } \\
\text { Quartile 2 }\end{array}$ & $\begin{array}{c}\text { SES } \\
\text { Quartile 3 }\end{array}$ & $\begin{array}{c}\text { SES } \\
\text { Quartile 4 }\end{array}$ & $F$ Statistic \\
\hline $\begin{array}{l}\text { Expressive Logic } \\
\text { Play games, music, sports, TV, }\end{array}$ & $2.85(.07)$ & $2.96(.05)$ & $2.89(.06)$ & $2.70(.09)$ & $85.93^{* * *}$ \\
video games (0, 4) & & & & & \\
Volunteer $(0,1)$ & $.27(.03)$ & $.30(.02)$ & $.39(.02)$ & $.51(.04)$ & $44.64^{* * *}$ \\
Parent council (0, $)$ & $.05(.01)$ & $.07(.01)$ & $.14(.02)$ & $.17(.03)$ & $371.99^{* * *}$ \\
Attend event $(0,1)$ & $.75(.03)$ & $.80(.02)$ & $.87(.02)$ & $.91(.02)$ & $377.21^{* * *}$ \\
& & & & & \\
Academics & & & & & \\
Average language grade (33.7, & $67.69(.57)$ & $70.19(.40)$ & $70.42(.53)$ & $73.60(.69)$ & $541.29^{* * *}$ \\
92) & & & & & \\
Days late (0, 78) & $6.02(.65)$ & $3.94(.36)$ & $3.59(.39)$ & $3.14(.64)$ & $173.52^{* * *}$ \\
Days absent $(0,86)$ & $10.79(.58)$ & $9.47(.37)$ & $9.20(.41)$ & $9.50(.65)$ & $69.03^{* * *}$ \\
Likes school (0, 2) & $1.74(.03)$ & $1.76(.02)$ & $1.80(.02)$ & $1.82(.04)$ & $65.66^{* * *}$ \\
Attended SLP (0, 1) & $.62(.03)$ & $.57(.02)$ & $.55(.03)$ & $.44(.04)$ & $176.11^{* * *}$ \\
\hline Note: Means are displayed, and standard deviations are in parentheses. Data are imputed. ${ }^{* * *} p<0.001$.
\end{tabular}

\section{Multilevel Models}

Which measures of parent engagement positively affect student cumulative literacy learning and summer literacy growth/loss? Table 4 shows the results for the Multilevel Models. Model 1 includes SES, other sociodemographic measures, and the controls. Not surprisingly, SES is a significant predictor for the two outcomes. SES Quartile 2 raises spring literacy outcomes by 1.7 months relative to Quartile 1. Those students in SES Quartile 3 have approximately 3.2 months of literacy gains in spring, and just over a one-month gain in summer. The fourth SES Quartile benefits from a 5-month gain in spring and 1.8-month gain in summer scores. In addition, males are 2.7 months behind in spring literacy, and experience almost a one-month literacy loss in summer growth when compared to their female peers. In spring literacy scores, students born in Canada fall behind their immigrant peers by 2.4 months.

To answer the first research question, Model 2 illustrates the effect of family resources and practices. With the addition of the three parent engagement mechanisms in predicting spring literacy scores, SES Quartile 2 is rendered insignificant, and shrinks the SES Quartiles 3 and 4 coefficients from the previous model to 2.2 and 3.5 months 
respectively. For summer scores, this group of covariates makes SES Quartile 3 insignificant and partially attenuates the effect for SES Quartile 4, which now raises summer literacy by 1.7 months. Also, the "male" effect disappears for summer literacy, and spring literacy decreases to a 1.9-month disadvantage in comparison to female students. Also, for students born in Canada, the literacy loss in spring outcomes (2.4 months) is slightly higher than those who are foreign-born.

In short, 14 parent engagement covariates are included in Model 3, and only five of them have a significant correlation to spring literacy scores, and none for summer growth. Of these, only two are positive: parents' aspirations and home resources. Regarding parents' aspirations, spring literacy outcomes increase by 2.3 months for community college, 3.7 months for university degree, and 4.8 months for post-graduate degree aspirations, relative to those families who hope their child will complete high school. Home resources have a significantly positive effect for spring literacy scores; as the amount of educational resources in the home increases, literacy increases by 1.2 months of schooling. Three measures show substantial negative effects for spring literacy outcomes. First, as the amount of time spent on homework increases, spring literacy decreases by 1.3 months. Second, if a student has a tutor, spring literacy decreases by 3.4 months. Third, more parent meetings with the teacher indicate a loss of 1.9 months in spring literacy. Notably, SES Quartile 4 continues to be influential for both outcomes.

\section{In terms of literacy achievement and SES, which students benefit the most from}

parent engagement practices? Before discussing the interactions in the final model, I will outline the results in Model 3. When student academic information and school-level covariates are added into the mix, all demographic covariates that had influential effects previously are not only reduced, but are now rendered insignificant, except for SES Quartile 4 for summer growth. ${ }^{8}$ In terms of the parent engagement measures for spring literacy, adding in academic covariates lessens the effect for most of the previously significant results, except it increased the negative effect of time on homework. Also, parents discussing school with children now positively predicts spring literacy scores (1.8 months).

8 Notably, there is greater variance in spring literacy than summer, and that difference could lead to different patterns in outcomes. Therefore, explanatory power is decreased in the summer models. Some parent engagement covariates have an effect on spring scores, but no effect on summer. The results that school-level variance is much smaller in summer learning is also found in previous research (Downey et al., 2004; Verachtert et al., 2009). 
Not surprisingly, higher grades in school correlate with higher test scores in spring outcomes ( 0.4 month, or 12 days), and a student liking school has a positive effect on spring literacy outcomes (1.4 months).

Finally, to answer the second research question, in Model 4, I test if the effects of parent engagement vary by parent SES (Table 4 only reports significant interactions). In comparison to respondents in SES Quartile 1, there is a positive relationship with spring literacy achievement when parents in SES Quartile 2 have aspirations for their child to attend graduate school, raising literacy scores by almost 4.6 months. Students in SES Quartiles 2 and 4 who spent more time on computers and other forms of technology average an increase in spring literacy by 1.5 and 2.5 months respectively. For summer growth, SES Quartile 3 interacted with parents' time playing games, music, sports, TV, and/or video games with their children. Surprisingly, this interaction reveals a negative effect on summer literacy of almost 4.4 months; as parents in this quartile do more fun activities with their child, children experience summer literacy loss. Overall, the results from the interactions show weak evidence that parent engagement is dependent on SES. Also, the findings from the interactions can be explained by the three parent engagement mechanisms which will be expanded upon in the next section. 


\section{Table 4}

Multi-level Regression of Spring Literacy Scores and Summer Growth

\begin{tabular}{|c|c|c|c|c|c|c|c|c|}
\hline & \multicolumn{2}{|c|}{ Model 1} & \multicolumn{2}{|c|}{ Model 2} & \multicolumn{2}{|c|}{ Model 3} & \multicolumn{2}{|c|}{ Model 4} \\
\hline & $\begin{array}{l}\text { Spring } \\
\text { literacy }\end{array}$ & $\begin{array}{l}\text { Summer } \\
\text { growth }\end{array}$ & $\begin{array}{l}\text { Spring } \\
\text { literacy }\end{array}$ & $\begin{array}{l}\text { Summer } \\
\text { growth }\end{array}$ & $\begin{array}{l}\text { Spring } \\
\text { literacy }\end{array}$ & $\begin{array}{l}\text { Summer } \\
\text { growth }\end{array}$ & $\begin{array}{l}\text { Spring } \\
\text { literacy }\end{array}$ & $\begin{array}{l}\text { Summer } \\
\text { growth }\end{array}$ \\
\hline \multicolumn{9}{|l|}{ Demographics } \\
\hline \multicolumn{9}{|l|}{$\begin{array}{l}\text { SES Quartile } 1 \\
\text { (ref) }\end{array}$} \\
\hline SES Quartile 2 & $.165(.072)^{*}$ & $.073(.049)$ & $.104(.070)$ & $.068(.049)$ & $.010(.067)$ & $.062(.050)$ & $-.406(.547)$ & $.067(.403)$ \\
\hline SES Quartile 3 & $.322(.077)^{* * *}$ & $.113(.052)^{*}$ & $.219(.077)^{* *}$ & $.101(.054)$ & $.121(.073)$ & $.097(.054)$ & $-.544(.585)$ & $.121(.429)$ \\
\hline SES Quartile 4 & $.502(.098)^{* * *}$ & $.184(.067)^{* *}$ & $.353(.100)^{* * *}$ & $.173(.070)^{*}$ & $.181(.096)$ & $.161(.071)^{*}$ & $-.553(.813)$ & $-.038(.594)$ \\
\hline Male & $-.272(.055)^{* * *}$ & $-.085(.037)^{*}$ & $-.185(.057)^{* *}$ & $-.070(.039)$ & $-.099(.055)$ & $-.067(.040)$ & $-.104(.055)$ & $-.061(.039)$ \\
\hline $\begin{array}{l}\text { English spoken } \\
\text { at home }\end{array}$ & $.160(.121)$ & $.004(.082)$ & $.085(.121)$ & $.018(.084)$ & $.063(.114)$ & $.020(.084)$ & $.086(.115)$ & $-.011(.085)$ \\
\hline Born in Canada & $-.242(.103)^{*}$ & $-.047(.064)$ & $-.237(.100)^{*}$ & $-.027(.065)$ & $-.158(.101)$ & $-.009(.068)$ & $-.153(.101)$ & $.002(.067)$ \\
\hline $\begin{array}{l}\text { Married/ } \\
\text { Common law }\end{array}$ & $-.048(.070)$ & $-.060(.047)$ & $-.055(.068)$ & $-.064(.047)$ & $-.065(.065)$ & $-.058(.048)$ & $-.069(.065)$ & $-.062(.047)$ \\
\hline \multicolumn{9}{|l|}{ Cultivation ethic } \\
\hline \multicolumn{9}{|l|}{$\begin{array}{l}\text { Parents' } \\
\text { Aspirations: }\end{array}$} \\
\hline \multicolumn{9}{|l|}{$\begin{array}{l}\text { High school } \\
\text { (ref) }\end{array}$} \\
\hline $\begin{array}{l}\text { Community } \\
\text { college }\end{array}$ & & & $.226(.083)^{* *}$ & $.059(.058)$ & $.187(.080)^{*}$ & $.055(.058)$ & $.136(.137)$ & $.218(.100)^{*}$ \\
\hline $\begin{array}{l}\text { University } \\
\text { degree }\end{array}$ & & & $.368(.087)^{* * *}$ & $.082(.060)$ & $.284(.083)^{* *}$ & $.074(.060)$ & $.148(.140)$ & $.115(.103)$ \\
\hline
\end{tabular}




\begin{tabular}{|c|c|c|c|c|c|c|c|c|}
\hline & \multicolumn{2}{|c|}{ Model 1} & \multicolumn{2}{|c|}{ Model 2} & \multicolumn{2}{|c|}{ Model 3} & \multicolumn{2}{|c|}{ Model 4} \\
\hline & $\begin{array}{l}\text { Spring } \\
\text { literacy }\end{array}$ & $\begin{array}{l}\text { Summer } \\
\text { growth }\end{array}$ & $\begin{array}{l}\text { Spring } \\
\text { literacy }\end{array}$ & $\begin{array}{l}\text { Summer } \\
\text { growth }\end{array}$ & $\begin{array}{l}\text { Spring } \\
\text { literacy }\end{array}$ & $\begin{array}{l}\text { Summer } \\
\text { growth }\end{array}$ & $\begin{array}{l}\text { Spring } \\
\text { literacy }\end{array}$ & $\begin{array}{l}\text { Summer } \\
\text { growth }\end{array}$ \\
\hline $\begin{array}{l}\text { Post-graduate } \\
\text { degree }\end{array}$ & & & $.477(.105)^{* * *}$ & $.095(.072)$ & $.393(.100)^{* * *}$ & $.085(.073)$ & $.157(.183)$ & $.318(.136)^{*}$ \\
\hline TV time & & & $.048(.046)$ & $-.017(.032)$ & $.049(.044)$ & $-.017(.032)$ & $.066(.090)$ & $-.044(.066)$ \\
\hline Computer time & & & $.053(.030)$ & $-.026(.021)$ & $.045(.029)$ & $-.027(.021)$ & $-.065(.057)$ & $-.039(.042)$ \\
\hline Home resources & & & $.122(.028)^{* * *}$ & $.003(.019)$ & $.095(.027)^{* * *}$ & $.000(.019)$ & $.088(.054)$ & $.020(.040)$ \\
\hline Extracurricular & & & $.011(.036)$ & $.021(.025)$ & $.018(.033)$ & $.021(.025)$ & $.019(.079)$ & $-.011(.056)$ \\
\hline Discuss school & & & $.158(.099)$ & $-.024(.069)$ & $.181(.094)^{*}$ & $-.020(.069)$ & $.228(.380)$ & $-.010(.279)$ \\
\hline \multicolumn{9}{|l|}{ Realist reaction } \\
\hline Hired tutor & & & $\begin{array}{l}-.343 \\
(.088)^{* * *}\end{array}$ & $-.055(.061)$ & $-.285(.085)^{* *}$ & $-.047(.061)$ & $.048(.209)$ & $-.026(.151)$ \\
\hline $\begin{array}{l}\text { Time spent on } \\
\text { homework }\end{array}$ & & & $-.126(.049)^{*}$ & $.027(.034)$ & $-.154(.047)^{* *}$ & $.031(.034)$ & $-.140(.093)$ & $.036(.067)$ \\
\hline Read with & & & $-.177(.093)$ & $-.015(.064)$ & $-.153(.088)$ & $-.015(.064)$ & $.210(.253)$ & $-.204(.184)$ \\
\hline Met teacher & & & $\begin{array}{l}-.190 \\
(.041)^{* * *}\end{array}$ & $-.016(.028)$ & $-.148(.039)^{* * *}$ & $-.012(.028)$ & $-.074(.169))$ & $.023(.124)$ \\
\hline \multicolumn{9}{|l|}{ Expressive logic } \\
\hline $\begin{array}{l}\text { Play games, } \\
\text { music, sports, } \\
\text { TV/video } \\
\text { games }\end{array}$ & & & $.005(.026)$ & $-.003(.018)$ & $-.005(.025)$ & $-.000(.018)$ & $-.041(.100)$ & $.078(.074)$ \\
\hline Volunteered & & & $.100(.060)$ & $-.003(.041)$ & $.078(.057)$ & $-.006(.041)$ & $-.176(.154)$ & $-.119(.114)$ \\
\hline Attended event & & & $.128(.074)$ & $-.006(.051)$ & $.086(.070)$ & $-.011(.051)$ & $.154(.271)$ & $-.079(.199)$ \\
\hline
\end{tabular}




\begin{tabular}{|c|c|c|c|c|c|c|c|c|}
\hline & \multicolumn{2}{|c|}{ Model 1} & \multicolumn{2}{|c|}{ Model 2} & \multicolumn{2}{|c|}{ Model 3} & \multicolumn{2}{|c|}{ Model 4} \\
\hline & $\begin{array}{l}\text { Spring } \\
\text { literacy }\end{array}$ & $\begin{array}{l}\text { Summer } \\
\text { growth }\end{array}$ & $\begin{array}{l}\text { Spring } \\
\text { literacy }\end{array}$ & $\begin{array}{l}\text { Summer } \\
\text { growth }\end{array}$ & $\begin{array}{l}\text { Spring } \\
\text { literacy }\end{array}$ & $\begin{array}{l}\text { Summer } \\
\text { growth }\end{array}$ & $\begin{array}{l}\text { Spring } \\
\text { literacy }\end{array}$ & $\begin{array}{l}\text { Summer } \\
\text { growth }\end{array}$ \\
\hline School council & & & $.001(.093)$ & $.050(.065)$ & $-.014(.088)$ & $.053(.065)$ & $-.087(.225)$ & $.130(.167)$ \\
\hline \multicolumn{9}{|l|}{ Academics } \\
\hline $\begin{array}{l}\text { Average lan- } \\
\text { guage grade }\end{array}$ & & & & & $.036(.004)^{* * *}$ & $.003(.002)$ & $.036(.004)^{* * *}$ & $.003(.002)$ \\
\hline Days late & & & & & $-.009(.004)^{*}$ & $.002(.003)$ & $-.008(.004)^{*}$ & $.001(.003)$ \\
\hline Days absent & & & & & $.002(.003)$ & $-.002(.002)$ & $.001(.003)$ & $-.003(.002)$ \\
\hline Likes school & & & & & $.141(.069)^{*}$ & $.000(.048)$ & $.141(.070)^{*}$ & $.005(.049)$ \\
\hline \multicolumn{9}{|c|}{ School-Level Variables } \\
\hline Public school & & & & & $-.289(.167)$ & $.096(.051)$ & $-.282(.166)$ & $.098(.050)^{*}$ \\
\hline School size & & & & & $.000(.001)$ & $.000(.000)$ & $.000(.001)$ & $.000(.000)$ \\
\hline \multicolumn{9}{|c|}{ Significant Interactions } \\
\hline $\begin{array}{l}\text { SES Quartile } 2 \\
\text { x Post-graduate } \\
\text { aspirations }\end{array}$ & & & & & & & $.458(.234)^{*}$ & \\
\hline $\begin{array}{l}\text { SES Quartile } \\
2 \times \text { Computer } \\
\text { time }\end{array}$ & & & & & & & $.146(.074)^{*}$ & \\
\hline $\begin{array}{l}\text { SES Quartile } \\
4 \text { x Computer } \\
\text { time }\end{array}$ & & & & & & & $.252(.109)^{*}$ & \\
\hline $\begin{array}{l}\text { SES Quartile } 3 \\
\text { x Play games, } \\
\text { music, sports, } \\
\text { TV/video } \\
\text { games }\end{array}$ & & & & & & & & $-.436(.208)^{*}$ \\
\hline
\end{tabular}




\begin{tabular}{|c|c|c|c|c|c|c|c|c|}
\hline & \multicolumn{2}{|c|}{ Model 1} & \multicolumn{2}{|c|}{ Model 2} & \multicolumn{2}{|c|}{ Model 3} & \multicolumn{2}{|c|}{ Model 4} \\
\hline & $\begin{array}{l}\text { Spring } \\
\text { literacy }\end{array}$ & $\begin{array}{l}\text { Summer } \\
\text { growth }\end{array}$ & $\begin{array}{l}\text { Spring } \\
\text { literacy }\end{array}$ & $\begin{array}{l}\text { Summer } \\
\text { growth }\end{array}$ & $\begin{array}{l}\text { Spring } \\
\text { literacy }\end{array}$ & $\begin{array}{l}\text { Summer } \\
\text { growth }\end{array}$ & $\begin{array}{l}\text { Spring } \\
\text { literacy }\end{array}$ & $\begin{array}{l}\text { Summer } \\
\text { growth }\end{array}$ \\
\hline \multicolumn{9}{|l|}{ Controls } \\
\hline Test interval & $-.003(.005)$ & $.002(.003)$ & $-.003(.004)$ & $.002(.003)$ & $-.011(.005)^{*}$ & $.002(.003)$ & $-.009(.005)$ & $.002(.003)$ \\
\hline Cohort & $-.204(.076)^{* *}$ & $.018(.046)$ & $-.239(.077)^{* *}$ & $.001(.049)$ & $\begin{array}{l}-.317 \\
(.081)^{* * *}\end{array}$ & $.003(.049)$ & $\begin{array}{l}-.301 \\
(.081)^{* * *}\end{array}$ & $.016(.049)$ \\
\hline Grade level & $.886(.038)^{* * *}$ & $-.045(.024)$ & $.885(.037)^{* * *}$ & $-.040(.024)$ & $.878(.039)^{* * *}$ & $-.023(.026)$ & $.881(.039)^{* * *}$ & $-.025(.026)$ \\
\hline Attended SLP & $\begin{array}{l}-.602 \\
(.075)^{* * *}\end{array}$ & $.048(.055)$ & $\begin{array}{l}-.506 \\
(.075)^{* * *}\end{array}$ & $.051(.057)$ & $\begin{array}{l}-.340 \\
(.077)^{* * *}\end{array}$ & $.063(.060)$ & $\begin{array}{l}-.330 \\
(.078)^{* * *}\end{array}$ & $.081(.061)$ \\
\hline Constant & $\begin{array}{l}411.832 \\
(153.529)^{* *}\end{array}$ & $\begin{array}{l}-36.094 \\
(92.819)\end{array}$ & $\begin{array}{l}480.607 \\
(153.743)^{* *}\end{array}$ & $\begin{array}{l}-1.410 \\
(98.775)\end{array}$ & $\begin{array}{l}637.224 \\
(162.076)^{* * *}\end{array}$ & $\begin{array}{l}-5.781 \\
(98.538)\end{array}$ & $\begin{array}{l}603.768 \\
(162.930)^{* * *}\end{array}$ & $\begin{array}{l}-34.337 \\
(98.559)\end{array}$ \\
\hline$F$ statistic & $66.54 * * *$ & 1.74 & $34.38 * * *$ & 1.03 & $30.04 * * *$ & 1.04 & $11.95 * * *$ & 1.04 \\
\hline \multicolumn{9}{|c|}{ Random-effect Coefficients: } \\
\hline $\mathrm{SD}$ (Intercept) & $.332(.049)$ & $.084(.034)$ & $.293(.044)$ & $.085(.035)$ & $.535(.135)$ & $.075(.039)$ & $.520(.141)$ & $.062(.044)$ \\
\hline SD (Residual) & $1.049(.020)$ & $.724(.013)$ & $1.015(.019)$ & $.723(.013)$ & $.944(.023)$ & $.721(.013)$ & $.929(.023)$ & $.708(.013)$ \\
\hline $\begin{array}{l}\text { Variance } \\
\text { Partition } \\
\text { Coefficient }\end{array}$ & .241 & .104 & .224 & .105 & .362 & .094 & .359 & .081 \\
\hline
\end{tabular}

Notes: $N=1,671$. Students are clustered in 230 schools. Standard errors in parentheses. Numbers are rounded to the nearest thousandth. Data are imputed. $* p<0.05, * * p<0.01, * * * p<0.001$. 


\section{Discussion and Conclusion}

Parent engagement is often expected to compensate for differences in family backgrounds, resources, and for those out-of-school times that can be so risky for disadvantaged students. This article provides a thorough investigation of various forms of parent engagement within the strategic testing ground of summer learning. It confirms patterns found in the literature that only examine the effects of parent engagement on school year or cumulative learning. In fact, these findings are even less optimistic for the assumption that parent engagement mitigates SES disparities in literacy achievement, especially when considering summer growth. In disentangling the results that arise in parent engagement research, and the powerful effect of SES on student achievement, I highlight three mechanisms that could underlie these associations that are useful in understanding the context and specification of the various forms of involvement.

First, in the cultivation ethic, parents' goal-driven approach to their child's education is the most straightforward mechanism, because it seems intuitive that parents would provide resources and offer encouragement to their children. Even though parents may or may not do these things, based on their child's academic progress, the variables included in this grouping generally have a positive relationship with educational outcomes. Notably, parents' aspirations are consistently found to be a potent predictor of educational achievement. Previous research supports this connection between higher-SES, student achievement, and high aspirations, but the direction of the relationship is unclear (e.g., Irwin \& Elley, 2013; Lareau, 2011). There are three possible explanations. First, high student achievement spurs higher aspirations, and, therefore, this is an instance of reverse causation. Second, parents' aspirations have a causal effect on student achievement. Third, it is possible that the relationship is reciprocal; parents who "aspire" have children who do better, which then encourages parents to aspire higher. Thus, parents' aspirations are shaped collectively by these two mechanisms: (1) cultivation ethic, which operates on a philosophy of parenting related to SES; and (2) a realist approach, in which parents react to a child's current accomplishments and adjust their expectations accordingly. As such, the interaction with SES Quartile 2 and post-graduate aspirations, and its positive influence on spring literacy, could be explained by this idea of a reciprocal relationship between parents' aspirations and student achievement. Relatedly, as found in the interaction effects, computer time could be another measure that is related to SES. It could also 
indicate that students who are doing well in school have more time to pursue computer-based activities at home.

Home resources and extracurricular activities are areas that could be explored further. Researchers suggest that there are minor differences in what lower- and higher-class families desire to do with their children during the summer months, but, rather, it is the lack of resources (e.g., money, time, transportation) that dictate extracurricular activities and learning materials (Bennett et al., 2012; Chin \& Phillips, 2004; Dermott \& Pomati, 2016). That is, all families want to provide these opportunities for their children, but higher-SES families are in a better position to immediately deliver these benefits because of economics, transportation, and/or more flexible work hours. However, Weininger and colleagues (2015) find that it is not income, but the mother's education level, that predicts higher involvement in extracurricular activities. Thus, low-income families with a mother with post-secondary education are more likely to have children in sports and arts lessons than those families where the mother has a high school education or less. Nonetheless, policies that focus on closing achievement gaps, or even opportunity gaps, can consider ways to get learning resources to disadvantaged communities (e.g., travelling lending libraries, sports teams within walking distance). Summer literacy programs, for instance, are a prime provider of books, technological resources, and special day trips that might be scarce for students from disadvantaged families (Davies \& Aurini, 2013; Kim \& Guryan, 2011)

Second, the realist reaction mechanism suggests parents react to their child's academic performance and respond accordingly. For example, if a child is struggling in school, parents might meet more often with teachers in order to gauge progress, hire a tutor, or provide more help with homework. Parental involvement in homework is one of the most common types of activities related to parent engagement, and it is also one that has been extensively researched and found wanting (e.g., Hill \& Tyson, 2009; Jeynes, 2005). Some researchers suggest that it is crucial to consider not only the quantity of parental help with homework, but the quality, in terms of the approach (e.g., supportive versus forceful) (Dumont et al., 2014; Moroni et al., 2015). Similarly, research on progress report meetings with the teacher corroborates the negative association reported in this study (e. g., Domina, 2005). Although, parents who have more formal meetings with the teacher are likely doing so because their child is already experiencing low achievement in school. Consequently, there are two important recommendations for future research 
to address with regards to the realist reaction. First, to truly see if the variables related to this mechanism could produce consistent positive effects, a longitudinal research design would be ideal. Second, it is important to note that quantitative research is simply measuring the occurrence of homework help, parent-teacher meetings, and tutoring. This highlights the need for qualitative research to investigate the processes that occur between parents and children when working on homework together and the interactions between parents and teachers in formal meetings.

Finally, the expressive logic mechanism is more about parent interest than it is about cultivation or reactivity. Perhaps parents get involved in volunteering at the school or join the parent council because they want to get involved, it is something that interests them, or their child asked them to come on a class field trip or attend a school event (e.g., Green et al., 2007). For these expressive forms of involvement - attending events, volunteering, and participation in school council-I find no significant effects on literacy scores. However, for summer literacy growth, SES Quartile 3 by parents' time playing with their children at home (e.g., games, sports) had a significant negative effect on this outcome in comparison to the lowest quartile. It could be that students in Quartile 3 who are underperforming in literacy achievement just spend more time doing these things with a parent. Again, this is likely related to parents' interest in doing these activities, rather than a concerted effort to boost achievement. Notably, expressive forms of parent engagement have mixed results in the literature, and when significant positive effects are found with these measures, they are weak (Domina, 2005; Jeynes, 2005; Robinson \& Harris, 2014). On the whole, these expressive variables do not affect student achievement, and parents likely do them for other reasons beyond getting their children ahead.

Perhaps taking an in-depth look at family practices in order to uncover the quality of interactions will help us understand why a subtle variable such as parents' aspirations yields consistently positive influence on academic outcomes. While parents from all levels of socio-economic strata are increasing their levels of involvement in their children's schooling and extracurricular activities (e.g., Bassok et al., 2016; Schaub, 2015), higher-SES children may benefit from a greater quality of engagement within the home, such as being read to by highly educated parents or participating in conversations about more complex topics. As such, the quality of home resources, not their quantity, is probably the most consequential for academic achievement. It is feasible to speculate that it is a combination of these factors - parents' expectations, home learning environments (e.g., 
seeing parents read for leisure), children's own learning dispositions (e.g., love of learning, feeling that they are "good" or "bad" readers, IQ) — that creates a perfect storm in influencing achievement (see Hillier \& Aurini, 2018). However, many of these processes are quite random, and would not be captured in a survey of family practices. It may be that the right stuff is difficult to measure (see Lareau, 2015). Lareau and Weininger (2003) note that when considering a concept such as cultural capital, it is important to study micro-interactional processes. More recently, qualitative studies have started to scratch the surface in examining student, teacher and parent interactions in schooling processes (e.g., Calarco, 2018; Lareau \& Muñoz, 2012; Ong-Dean, 2009). In so doing, they demonstrate how students and parents enact their personal resources (their capital) in order to ensure academic advantage or success.

\section{Limitations}

While this study presents a new approach to analyzing parent engagement in a seasonal research design, there are several limitations that warrant future research. First, this study relies on parental reports for most of the variables of interest. While it is expected that parents are reliable indicators of their own levels of engagement, Kohl and colleagues (2000) suggest that multiple-reporter ratings - which can include surveys from teachers and children - allow for a more valid assessment of parent engagement. Also, because I do not know how teachers would rate parents' involvement levels, or how teachers would rate their own advocacy of parent involvement in the class and at home, I cannot fully account for institutional effects of how schools and teachers foster greater levels of engagement (Dauber \& Epstein, 1993). Second, the current study relied on cross-sectional parent survey data. Certainly, longitudinal data examining the same variables would allow for greater understanding of the strength of the predictors. Because parent engagement can change over time, often waning as children get older (Catsambis, 2001), longitudinal data on parent engagement could not only serve to track changes in parents' involvement, but also measure how this involvement affects literacy outcomes in the long term. Third, this study only accounts for the effects of parent engagement on children's literacy outcomes. It does not account for the other positive effects that involvement might have on children's behaviour or school attendance. In addition, parent engagement 
studies often do not consider the benefits that involvement initiatives might have on parents. Parent programs may increase parents' sense of efficacy; the feeling that they can help their child with their struggles with literacy (Aurini et al., 2016). This relates to the COVID-19 school closures, since school resources (e.g., food programs, educational guidance, and daily structure) and family-school connections are important for low-SES families and students who are at-risk. This is something that could be investigated further in future research.

Overall, this study set out to examine the effect of parent engagement for spring literacy outcomes (cumulative learning) versus summer growth. What does summer learning tell us about parental involvement? Despite the intuitive appeal of parent engagement and its increasing recognition in school policy, it simply lacks the kind of impact on student literacy achievement that educational policy makers and practitioners want. Since the story here seems to come back to SES backgrounds, emphasizing other interventions (besides parent engagement) in literacy achievement, such as summer literacy camps or after-school homework support, would be beneficial. This study provides a framework for considering parent engagement within a seasonal research design. Future research could consider parent engagement and similar policy interventions and the effects on student academic achievement within a seasonal research design. 


\section{Appendix 1}

\section{Table 1}

\section{Independent Variable Definitions}

\begin{tabular}{ll}
\hline $\begin{array}{l}\text { Level-1 variables } \\
\text { Demographics }\end{array}$ & \\
SES Quartiles & $\begin{array}{l}\text { SES measure split into quartiles. Parent education, other parent education, } \\
\text { household income combined from three questions on the survey: }(1) \text { What level } \\
\text { of education have you completed? }(2) \text { What level of education has your child's } \\
\text { other parent completed? }(1=\text { Elementary school, } 2=\text { Some high school, } 3=\end{array}$ \\
& High school graduate, $4=$ Private technical college, $5=$ Community college, $6=$ \\
& University B.A./B.Sc., $7=$ University postgraduate); and 3) Total income of all \\
& household members from all sources during the last 12 months: $1=<\$ 15,000,2$ \\
& $=\$ 15,000$ to $<\$ 30,000,3=\$ 30,000$ to $<\$ 45,000,4=\$ 45,000$ to $<\$ 60,000,5=$ \\
& $\$ 60,000$ to $<\$ 80,000,6=\$ 80,000$ to $<\$ 100,000,7=\$ 100,000$ to $\$ 200,000,8=$ \\
& $>\$ 200000$
\end{tabular}

Male $\quad 0=$ no, $1=$ yes

English spoken at $\quad 0=$ no, $1=$ yes

home

Born in Canada $\quad 0=$ no, $1=$ yes

Married/common $\quad 0=$ no, $1=$ yes

law

Mechanisms of parent engagement

1) Cultivation Ethic (aspirations, values/rules about screen time and homework, resources)

Aspirations

"What is the highest level of education you hope your child will complete?"

1 = Finish High School/Apprenticeship, 2 = Community College, 3 = University degree (e.g., B.A.), 4 = Postgraduate degree (e.g., M.A., PhD)

TV time

"In a typical week during the school year, how much time does your child ....?" Watch television, $0=$ Never, $1=1-4$ hours, $2=5-10$ hours, $3=$ More than 10 hours

Computer time

Spend on the computer doing non-school activities (e.g., online games, Facebook, email, etc.), $0=$ Never, $1=$ Less than hour, $2=1-4$ hours, $3=$ More than 5 hours

Home resources Number of resources that parents said they have in the house: books, newspaper, magazines, computer, Internet, arts/craft materials, music $(\min =1, \max =6)$

Extracurricular Number of extracurricular activities child participated in past year: sports, music, art, dance, library, religious club, social group (e.g., Girl Guides), language class, tutoring $(\min =1, \max =7)$ 
Discuss school "Do you discuss school with your child several times per week?" $0=$ no, $1=$ yes

\section{2) Realist Reaction}

Hired tutor

Time spent on homework

Read with

Met teacher
$0=$ no tutor, $1=$ parent hired a private tutor

Spend on homework/school related activities (e.g., project, study for a test) $0=$ Never, $1=$ Less than hour, $2=1-4$ hours, $3=$ More than 5 hours

$0=$ no, $1=$ read with child several times per week

$0=$ no, $1=$ attended a parent-teacher meeting (e.g., progress report interviews), $2=$ attended parent-teacher meeting and met privately with child's teacher to discuss schooling

\section{3) Expressive Logic}

Play games, music, sports, TV, video games

Volunteer School council Attend event

Academics

Average language grade $^{\mathrm{a}}$

Days late ${ }^{\mathrm{a}}$

Days absent ${ }^{\mathrm{a}}$

Likes school

Level-2 variables

Public school ${ }^{\text {b }}$

School size ${ }^{\mathrm{b}}$

$0=$ Catholic, $1=$ public

School's total enrolment

\section{Controls}

Test interval

Cohort

Grade level $^{\mathrm{a}}$

Attended SLPa
Number of these activities that parent does with child several times per week

"During this past school year, have you done the following at your child's school?"

$0=$ no, $1=$ yes

Average of final reading, writing and oral communication report card grades

Accumulated total from final report card

Accumulated total from final report card

"Thinking of this past year, how much does your child like coming to school?" ( 0 $=$ not at all, $1=$ somewhat, $2=$ a lot) surveys. 


\section{Appendix 2}

Table 2

Descriptive Statistics Before and After Imputation

\begin{tabular}{|c|c|c|c|c|}
\hline & $\begin{array}{l}\text { Minimum, } \\
\text { Maximum }\end{array}$ & $N$ & $\begin{array}{l}\text { Mean } \\
\text { (Standard } \\
\text { Deviation) }\end{array}$ & $\begin{array}{l}\text { Imputed Mean } \\
(S D) \\
(N=1671)\end{array}$ \\
\hline \multicolumn{5}{|l|}{ Outcomes } \\
\hline Spring literacy & $0,12.9$ & 1671 & $2.23(1.35)$ & Same \\
\hline Summer growth/Loss & $-11.4,4.3$ & 1671 & $-.02(.74)$ & Same \\
\hline \multicolumn{5}{|l|}{ Demographics } \\
\hline SES & $-4.96,4.91$ & 1328 & $-.22(2.08)$ & Same \\
\hline Male & 0,1 & 1541 & $.49(.50)$ & $.49(.50)$ \\
\hline English spoken at home & 0,1 & 1614 & $.90(.30)$ & $.90(.30)$ \\
\hline Born in Canada & 0,1 & 1646 & $.81(.39)$ & $.81(.39)$ \\
\hline Married/Common law & 0,1 & 1664 & $.79(.40)$ & $.80(.40)$ \\
\hline \multicolumn{5}{|l|}{ Mechanisms of Parent Engagement } \\
\hline \multicolumn{5}{|l|}{ Cultivation Ethic } \\
\hline Aspirations & 1,4 & 1671 & $2.55(.94)$ & Same \\
\hline TV time & 0,3 & 1663 & $1.56(.57)$ & $1.56(.57)$ \\
\hline Computer time & 0,3 & 1657 & $1.65(.89)$ & $1.65(.89)$ \\
\hline Home resources & 1,6 & 1650 & $3.51(1.07)$ & $3.50(1.08)$ \\
\hline Extracurricular & 1,7 & 1225 & $1.74(.88)$ & $1.71(.90)$ \\
\hline Discuss school & 0,1 & 1671 & $.90(.30)$ & Same \\
\hline \multicolumn{5}{|l|}{ Realist Reaction } \\
\hline Hired tutor & 0,1 & 1649 & $.10(.30)$ & $.10(.30)$ \\
\hline Time on homework & 0,3 & 1656 & $2.03(.55)$ & $2.03(.55)$ \\
\hline Read with & 0,1 & 1671 & $.90(.31)$ & Same \\
\hline Met teacher & 0,2 & 1671 & $1.36(.69)$ & Same \\
\hline \multicolumn{5}{|l|}{ Expressive Logic } \\
\hline $\begin{array}{l}\text { Play games, music, sports, TV/ } \\
\text { video }\end{array}$ & 0,4 & 1671 & $2.88(1.17)$ & Same \\
\hline Volunteer & 0,1 & 1671 & $.34(.47)$ & Same \\
\hline School council & 0,1 & 1671 & $.10(.29)$ & Same \\
\hline
\end{tabular}




\begin{tabular}{lllll}
\hline & $\begin{array}{l}\text { Minimum, } \\
\text { Maximum }\end{array}$ & $N$ & $\begin{array}{l}\text { Mean } \\
\text { (Standard } \\
\text { Deviation) }\end{array}$ & $\begin{array}{l}\text { Imputed Mean } \\
(\text { SD }) \\
(N=1671)\end{array}$ \\
\hline Attend event & 0,1 & 1671 & $.82(.38)$ & Same \\
$\begin{array}{l}\text { Academics } \\
\text { Average language grade }\end{array}$ & $33.67,92$ & 1589 & $70.25(9.73)$ & $70.25(9.73)$ \\
Days late & 0,78 & 1363 & $4.19(8.25)$ & $4.21(8.31)$ \\
$\begin{array}{l}\text { Days absent } \\
\text { Likes school }\end{array}$ & 0,86 & 1484 & $9.60(8.54)$ & $9.69(8.58)$ \\
& 0,2 & 1322 & $1.77(.45)$ & $1.78(.45)$ \\
$\begin{array}{l}\text { School level variables } \\
\text { Public school }\end{array}$ & & & & \\
School size & 0,1 & 1360 & $.74(.44)$ & $.77(.46)$ \\
& 77,667 & 1172 & $323.48(130.02)$ & $305.77(138.86)$ \\
Controls & & & & \\
Test interval & & & & \\
Cohort & $42.12,115.98$ & 1671 & $85.58(8.07)$ & Same \\
Grade level & 2010,2011 & 1671 & $2010.48(.50)$ & Same \\
Attended SLP & 1,3 & 1671 & $1.87(.78)$ & Same \\
\hline & 0,1 & 1204 & $.51(.45)$ & $.56(.51)$ \\
\hline
\end{tabular}




\section{References}

Alexander, K. L., Entwisle, D. R., \& Olson, L. S. (2007). Lasting consequences of the summer learning gap. American Sociological Review, 72, 167-180.

Aurini, J., Milne, E., \& Hillier, C. (2016). The two sides of "vigilance": Parent engagement and its relationship to school connections, responsibility, and agency. In W. Lehmann (Ed.), Education and society: Canadian perspectives (pp. 90-102). Oxford University Press.

Australian Government, Department of Education, Employment and Workplace Relations (2012). Family-school partnerships framework: A guide for schools and families. http://www.familyschool.org.au/pdf/framework.pdf

Bassok, D., Finch, J. E., Lee, R., Reardon, S. F., \& Waldfogel, J. (2016). Socioeconomic gaps in early childhood experiences: 1998 to 2010. AERA Open, 2(3), 1-22.

Bennett, P. R., Lutz, A. C., \& Jayaram, L. (2012). Beyond the schoolyard: The role of parenting logics, financial resources, and social institutions in the social class gap in structured activity participation. Sociology of Education, 85(2), 131-157.

Borman, G. D., Benson, J., \& Overman, L. T. (2005). Families, schools, and summer learning. The Elementary School Journal, 106(2), 131-150.

Bourdieu, P. (1998). The forms of capital. In A. H. Halsey, H. Lauder, P. Brown, \& A. Stuart Wells (Eds.), Education: Culture, economy and society (pp. 46-58). Oxford University Press.

Burkam, D. T., Ready, D. D., Lee, V. E., \& LoGerfo, L. F. (2004). Social-class differences in summer learning between kindergarten and first grade: Model specification and estimation. Sociology of Education, 77(1), 1-31.

Calarco, J. M. (2018). Negotiating opportunities: How the middle class secures advantages in school. Oxford University Press.

Catsambis, S. (2001). Expanding knowledge of parental involvement in children's secondary education: Connections with high school seniors' academic success. Social Psychology of Education, 5(2), 149-177. 
Chin, T., \& Phillips, M. (2004). Social reproduction and child rearing practices: Social class, children's agency, and the summer activity gap. Sociology of Education, 77(3), 185-210.

Cooper, H., Robinson, J. C., \& Patall, E. A. (2006). Does homework improve academic achievement? A synthesis of research, 1987-2003. Review of Educational Research, 76(1), 1-62.

Dauber, S. L., \& Epstein, J. L. (1993). Parents' attitudes and practices of involvement in inner city elementary and middle schools. In N. F. Chavkin (Ed.), Families and schools in a pluralistic society (pp. 53-71). SUNY Press.

Davies, S., \& Aurini, J. (2010-2014). CODE summer literacy \& numeracy project reports. http://www.ontariodirectors.ca/summer_literacy.html

Davies, S., \& Aurini, J. (2013). Summer learning inequality in Ontario. Canadian Public Policy, 30(2), 287-307.

Dermott, E., \& Pomati, M. (2016). 'Good' parenting practices: How important are poverty, education and time pressure? Sociology, 50(1), 125-142.

Domina, T. (2005). Leveling the home advantage: Assessing the effectiveness of parental involvement in elementary school. Sociology of Education, 78(3), 233-249.

Downey, D. B. (2018). Schools as great distractors: Why socioeconomic-based achievement gaps persist. In J. Mehta \& S. Davies (Eds.), Education in a new society: Renewing the sociology of education (pp. 334-344). University of Chicago Press.

Downey, D. B., von Hippel, P. T., \& Broh, B. A. (2004). Are schools the great equalizer? Cognitive inequality during the summer months and the school year. American Sociological Review, 69(5), 613-635.

Downey, D. B., von Hippel, P. T., \& Hughes, M. (2008). Are "failing" schools really failing? Using seasonal comparison to evaluate school effectiveness. Sociology of Education, 81(3), 242-270.

Dumont, H., Trautwein, U., Nagy, G., \& Nagengast, B. (2014). Quality of parental homework involvement: Predictors and reciprocal relations with academic 
functioning in the reading domain. Journal of Educational Psychology, 106(1), $144-161$.

El Nokali, N. E., Bachman, H. J., \& Votruba-Drzal, E. (2010). Parent involvement and children's academic and social development in elementary school. Child Development, 81(3), 988-1005.

Englund, M. M., Luckner, A. E., Whaley, G. J., \& Egeland, B. (2004). Children's achievement in early elementary school: Longitudinal effects of parental involvement, expectations, and quality of assistance. Journal of Educational Psychology, 96(4), 723-730.

Epstein, J. L. (1988). Homework practices, achievements, and behaviors of elementary school students (Report No. 26). Johns Hopkins University, Center for Research on Elementary and Middle Schools.

Epstein, J. L. (1995). School/family/community partnerships: Caring for the children we share. Phi Delta Kappan, 76(9), 701-712.

Fan, W., Williams, C. M., \& Wolters, C. A. (2012). Parental involvement in predicting school motivation: Similar and differential effects across ethnic groups. The Journal of Educational Research, 105(1), 21-35.

Fan, X., \& Chen, M. (2001). Parental involvement and students' academic achievement: A meta-analysis. Educational Psychology Review, 13(1), 1-22.

Galindo, C., \& Sheldon, S. B. (2012). School and home connections and children's kindergarten achievement gains: The mediating role of family involvement. Early Childhood Research Quarterly, 27(1), 90-103.

Green, C. L., Walker, J. M. T., Hoover-Dempsey, K. V., \& Sandler, H. M. (2007). Parents' motivations for involvement in children's education: An empirical test of a theoretical model of parental involvement. Journal of Educational Psychology, $99(3), 532-544$.

Heyns, B. (1978). Summer learning and the effects of schooling. Academic Press.

Hill, N. E., \& Tyson, D. F. (2009). Parental involvement in middle school: A metaanalytic assessment of the strategies that promote achievement. Developmental Psychology, 45(3), 740-763. 
Hillier, C., \& Aurini, J. (2018). The summer reading blues: Children's accounts of summer literacy practices. In P. Albanese, L. Tepperman, \& E. Alexander (Eds.), Reading sociology: Canadian perspectives (3rd ed., pp. 64-68). Oxford University Press.

Horvat, E. M., Weininger, E. B., \& Lareau, A. (2003). From social ties to social capital: Class differences in the relations between schools and parent networks. American Educational Research Journal, 40(2), 319-351.

Irwin, S., \& Elley, S. (2013). Parents' hopes and expectations for their children's future occupations. The Sociological Review, 61(1), 111-130.

Jeynes, W. H. (2005). A meta-analysis of the relation of parental involvement to urban elementary school student academic achievement. Urban Education, 40(3), $237-269$.

Kim, J. S., \& Guryan, J. (2011, March 3-5). Addressing socio-economic disparities in non-cognitive and cognitive skills through summer book reading: Results from a longitudinal randomized experiment [Paper presentation]. Annual Meeting of the Society for Research on Educational Effectiveness, Washington, DC, United States.

Kim, J. S., \& Quinn, D. M. (2013). The effects of summer reading on low-income children's literacy achievement from kindergarten to grade 8: A meta-analysis of classroom and home interventions. Review of Educational Research, 83(3), 386-431.

Kohl, G. O., Lengua, L. J., \& McMahon, R. J. (2000). Parent involvement in school conceptualizing multiple dimensions and their relations with family and demographic risk factors. Journal of School Psychology, 38(6), 501-523.

Lareau, A. (1989). Home advantage: Social class and parental involvement in elementary education. Falmer.

Lareau, A. (2011). Unequal childhoods: Class, race, and family life (2nd ed.). University of California Press.

Lareau, A. (2015). Cultural knowledge and social inequality. American Sociological Review, 80, 1-27. 
Lareau, A., \& Muñoz, V. L. (2012). "You're not going to call the shots": Structural conflicts between the principal and the PTO at a suburban public elementary school. Sociology of Education, 85(3), 201-218.

Lareau, A., \& Weininger, E. B. (2003). Cultural capital in educational research: A critical assessment. Theory and Society, 32(5/6, Special Issue), 567-606.

McNeal, R. B. (2012). Checking in or checking out? Investigating the parent involvement reactive hypothesis. The Journal of Educational Research, 105, 79-89. https://doi. org/10.1080/00220671.2010.519410

Moroni, S., Dumont, H., Trautwein, U., Niggli, A., \& Baeriswyl, F. (2015). The need to distinguish between quantity and quality in research on parental involvement: The example of parental help with homework. The Journal of Educational Research, $108(5), 417-431$.

Ong-Dean, C. (2009). Distinguishing disability: Parents, privilege, and special education. University of Chicago Press.

Ontario Ministry of Education. (2010). Parents in partnership: A parent engagement policy for Ontario schools. http://www.edu.gov.on.ca/eng/parents/involvement/ PE Policy2010.pdf

Patall, E. A., Cooper, H., \& Robinson, J. C. (2008). Parent involvement in homework: A research synthesis. Review of Educational Research, 78, 1039-1101.

Raudenbush, S. W., \& Eschmann, R. D. (2015). Does schooling increase or reduce social inequality? Annual Review of Sociology, 41, 443-70.

Robinson, K., \& Harris, A. L. (2014). The broken compass: Parental involvement with children's education. Harvard University Press.

Schaub, M. (2010). Parenting for cognitive development from 1950 to 2000: The institutionalization of mass education and the social construction of parenting in the United States. Sociology of Education, 83(1), 46-66.

Schaub, M. (2015). Is there a home advantage in school readiness for young children? Trends in parent engagement in cognitive activities with young children, 19912001. Journal of Early Childhood Research, 13(1), 47-63. 
Slates, S. L., Alexander, K. L., Entwisle, D. R., \& Olson, L. S. (2012). Counteracting summer slide: Social capital resources within socioeconomically disadvantaged families. Journal of Education for Students Placed at Risk, 17(3), 165-185.

Snijders, T. A. B., \& Bosker, R. J. (2012). Multilevel analysis: An introduction to basic and advanced multilevel modeling (2nd ed.). SAGE.

U.S. Department of Education. (2004). Parental involvement: Title I, Part A: Nonregulatory guidance. https://www2.ed.gov/programs/titleiparta/parentinvguid.doc

Verachtert, P., Van Damme, J., Onghena, P., \& Ghesquière, P. (2009). A seasonal perspective on school effectiveness: Evidence from a Flemish longitudinal study in kindergarten and first grade. School Effectiveness and School Improvement: An International Journal of Research, Policy and Practice, 20(2), 215-233.

von Hippel, P. (2009). How to impute interactions, squares, and other transformed variables. Sociological Methodology, 39(1), 265 291.

von Hippel, P., \& Workman, J. (2016). From kindergarten through second grade, U.S. children's obesity prevalence grows only during summer vacations. Obesity, 24(11), 2296-2300.

Weininger, E. B., Lareau, A., \& Conley, D. (2015). What money doesn’t buy: Class resources and children's participation in organized extracurricular activities. Social Forces, 94(2), 479-503. 